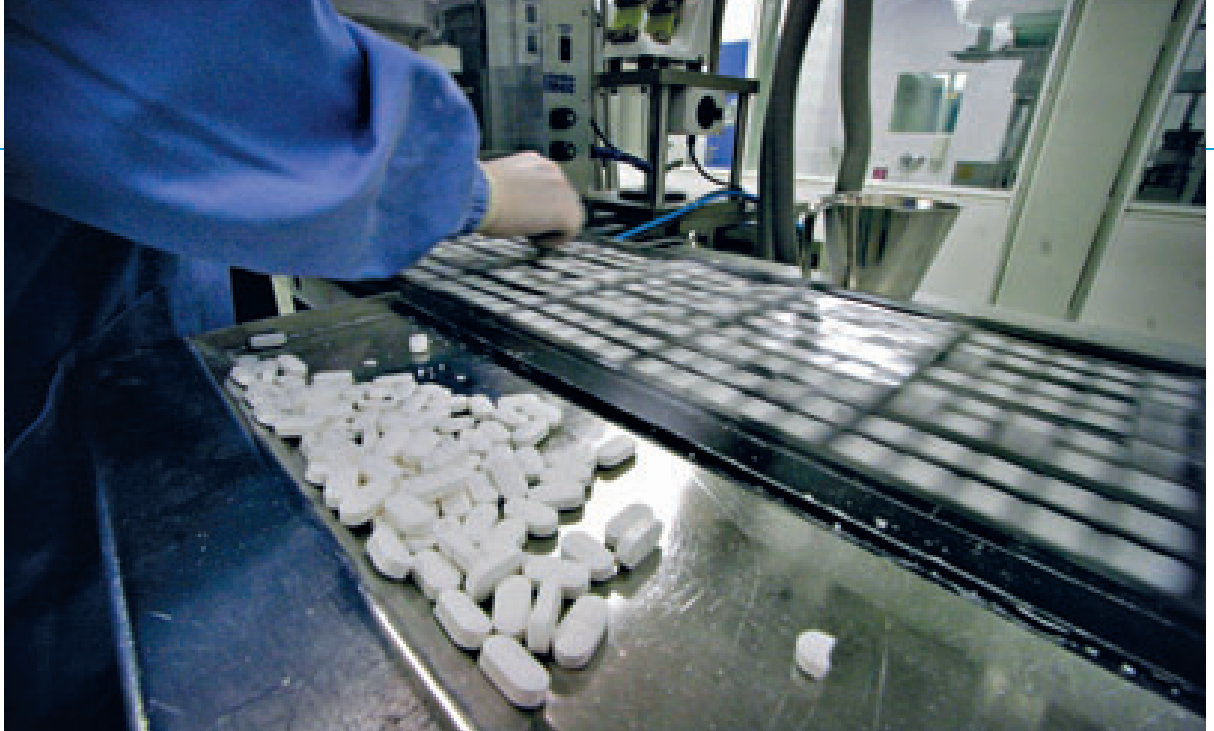

Illustrasjonsfoto SCANPIX

\title{
Acetylsalisylsyre beskytter mot kolorektal kreft
}

\author{
Ved behandling med acetylsalisylsyre \\ 75 mg/dag oppnår man lavere risiko \\ for utvikling av kolorektal kreft. Slik \\ behandling anbefaler man likevel ikke.
}

I en populasjonsbasert pasient-kontroll-studie var 2279 pasienter og 2907 kontrollpersoner tilfeldig utvalgt og matchet for alder, kjønn og bopel. Deltakerne fylte ut spørreskjemaer om kost og livsstil og inntak av ikke-steroide antiinflammatoriske legemidler (1).

354 pasienter $(15,5 \%)$ var i behandling med acetylsalisylsyre sammenliknet med $18,1 \%$ av kontrollpersonene. Slik behandling var forbundet med nedsatt risiko for kolorektal kreft (OR 0,78; $95 \%$ KI 0,65- 0,92). Sammenhengen var allerede til stede etter inntak av acetylsalisylsyre i ett år, men ble mer uttalt med lengre tids bruk. Andre NSAID-midler var også assosiert med en nedsatt risiko for kolorektal kreft, men det kunne ikke påvises effekt på overordnet mortalitet eller kolorektal kreftspesifikk overlevelse.

- Acetylsalisylsyre har i stort sett alle undersøkelser vist å være forbundet med redusert risiko for kolorektal kreft og regresjon av adenomer. Når det ikke anbefales, skyldes det kardiovaskulære og gastrointestinale bivirkninger. Imidlertid anbefaler man acetylsalisylsyre $75 \mathrm{mg}$ til alle pasienter med iskemisk hjertesykdom med mindre det er kontraindikasjoner. Min konklusjon er at man skal individualisere behandlingen, sier Claus P. Hovendal, Kirurgisk Afdeling A, Odense Universitetshospital til Ugeskrift for Læger.

\section{Erlend Hem}

erlend.hem@medisin.uio.no

Tidsskriftet

\section{Litteratur}

1. Din FV, Theodoratou E, Farrington SM et al. Effect of aspirin and NSAID on risk and survival from colorectal cancer. Gut 2010, doi: 10.1136/ gut.2009.203000.

\section{Neonatalt D-vitaminnivå og risiko for schizofreni}

Både lav og høy konsentrasjon av neonatalt D-vitamin er forbundet med økt risiko for schizofreni, ifølge en ny studie. Resultatene tyder på at D-vitaminet har innvirkning på cerebral utvikling og senere mental helse (Arch Gen Psychiatry 2010; 67: 889-94).

Neonatalt nivå av D-vitamin ble undersøkt i en pasient-kontroll-studie med 424 personer med schizofreni og 424 matchede kontrollpersoner. Konsentrasjonen av neonatalt 25 -hydroksyvitamin $D_{3}$ ble unders $ø$ kt og inndelt $i$ kvintiler.

De med høyest risiko for schizofreni hadde D-vitaminnivå i den laveste eller i den høyeste kvintilen. At lavt nivå gir økt risiko for schizofreni, stemte med tidligere studier. Det var uventet at også de i den høyeste kvintilen hadde forhøyet risiko.

\section{Lungesymptomer hos oljeutslippseksponerte fiskere}

I 2002 førte et stort utslipp fra oljetankeren Prestige til kraftig forurensning i NordSpania. De som deltok i opprydningsarbeidet, hadde to år etterpå respiratoriske symptomer, kromosomendringer og forhøyede markører for luftveisskade i utåndingsluften (Ann Intern Med 2010; 153: 489-98).

De lokale fiskerne som hadde deltatt i opprydningen i minst 15 dager $(n=501)$ ble sammenliknet med ikke-eksponerte fiskere ( $\mathrm{n}=177$ ). De eksponerte hadde $\varnothing \mathrm{kt}$ risiko for symptomer fra de nedre luftveiene og høyere nivå av markører for pulmonalt oksidativt stress, og en høyere andel hadde strukturelle kromosomendringer i sirkulerende lymfocytter.

Det er overraskende at midlertidig eksponering kan gi inflammasjon og oksidativt stress i nedre luftveier og kromosomskader i lymfocytter to år etter, ifølge Ugeskrift for Læger.

\section{Effekt av glukosamin og kondroitin ved artrose?}

\section{Glukosamin og kondroitin har ingen}

klinisk effekt ved artrose i hofte og kne.

I løpet av de siste ti årene har det vært en kraftig økning i bruk av glukosamin og kondroitin ved artrose i hofte og kne. Imidlertid viser randomiserte studier av effekten av disse legemidlene motstridene resultater. Nå har en internasjonal forskergruppe undersøkt effekten av glukosamin og kondroitin på leddsmerter og radiologisk progresjon av artrose i hofte og kne (1).

En metaanalyse omfattet ti randomiserte studier av til sammen 3800 pasienter med artrose. Verken glukosamin, kondroitin eller en kombinasjon av disse hadde klinisk relevant effekt på smerteopplevelse eller leddspaltehøyde, sammenliknet med placebo. Analysen viste dessuten at de estimerte forskjellene mellom legemiddel og placebo var gjennomsnittlig mindre i studier uavhengig av industrien enn i de som var sponset av industrien.

- Denne metaanalysen føyer seg til rekken av studier av glukosamin og kondroitin, som ikke påviser effekt. For den store pasientgruppen med artrose er det nedslående at det ikke finnes et legemiddel som kan dokumentere redusert brusknedbryting, sier spesialist i allmennmedisin, stipendiat Hilde Moseby Berge ved Norges idrettshøgskole.

- Paradokset er at mens glukosamin og kondroitin har vært gjenstand for mange studier, så kan helsekost selges fritt med reklametekster langt fra den vitenskapelige sannheten. Selv om ikke utgiftene dekkes av helsevesenet i Norge, bør pasientene ha krav på riktig informasjon om produkter de selv bekoster. Vi kan slutte oss til anbefalingen til disse forskerne om ikke å forskrive glukosamin og kondroitin til nye pasienter. Vi kan dessuten legge til at allerede pågående behandling heller ikke bør forlenges, sier Berge.

\section{Trine B. Haugen \\ trine.b.haugen@hf.hio.no \\ Tidsskriftet}

Litteratur

Wandel S, Jüni P, Tendal B et al. Effects of glucosamine, chondroitin, or placebo in patients with osteoarthritis of hip or knee: network meta-analysis. BMJ 2010; 341: c4675. 